\title{
Combined Effect of Irradiation and Ageing Condition on Physicochemical and Microbial Quality of Hanwoo Eye of Round
}

\author{
Dong-Gyun Yim¹, Cheorun Jo², Hyun-Joo Kim², Ju-Su Cha, Hyun Cheol Kim, and Ki-Chang Nam* \\ Department of Animal Science and Technology, Sunchon National University, Suncheon 540-950, Korea \\ ${ }^{1}$ Department of Health Administration and Food Hygiene, Jinju Health College, Jinju 660-757, Korea \\ ${ }^{2}$ Department of Agricultural Biotechnology, Center for Food and Bioconvergence, and Research Institute \\ of Agriculture and Life Sciences, Seoul National University, Seoul 151-921, Korea
}

\begin{abstract}
The combined effects of electron-beam irradiation and ageing of beef were examined. The irradiated samples at dose of 0 or $2 \mathrm{kGy}$ were kept and analyzed for the microbial growth, shear values, meat color, and nucleotide-related flavor compounds at different ageing temperatures $\left(2,10\right.$, or $\left.25^{\circ} \mathrm{C}\right)$ for $8 \mathrm{~d}$. The irradiation effect on inactivation of foodborne pathogens was also investigated. The population of Listeria monocytogenes and E. coli $\mathrm{O} 157: \mathrm{H} 7$ inoculated in beef samples decreased in proportion to the irradiation dose, showing $\mathrm{D}_{10}$ values of 0.66 and $0.65 \mathrm{kGy}$ respectively. The irradiated beef eye of round had lower number of total aerobic bacteria (TAB) than nonirradiated one during the storage, but the TAB increased with higher ageing temperature $(p<0.05)$. Especially, TAB increased sharply in non-irradiated samples aged at $25^{\circ} \mathrm{C}$ after $4 \mathrm{~d}(p<0.05)$. With increasing ageing temperature and ageing time, shear force values decreased $(p<0.05)$. The color $\mathrm{a}^{*}$ values of the irradiated beef were lower than those of the non-irradiated throughout the ageing period $(p<0.05)$. As ageing time and temperature increased, the amounts of inosine monophosphate decreased and the hypoxanthine increased $(p<0.05)$. Relatively high ageing temperature could be used at irradiated beef eye of round to shorten the ageing time.
\end{abstract}

Keywords: beef, irradiation, ageing temperature, pathogens, meat quality

Received January 8, 2015; Revised April 14, 2015; Accepted May 14, 2015

\section{Introduction}

Consumers' demand for microbiologically safe and high quality meat and meat products has been increasing (Artes et al., 2007). Therefore meat scientists have made an effort to develop new technologies that can be used not only to secure the safety issues but improve also the quality of meat (Artes et al., 2007). One promising tool of numerous food technologies available to provide food protection is food irradiation. Ionizing radiation is an excellent potential technology improving microbiological safety and extending shelf life of meat products, without compromising the nutritional properties and sensory quality of food (WHO, 1999). The wholesomeness of irradiated foods has been accepted by international expert organizations such as the World Health Organization (WHO), the Food and Agriculture Organization (FAO), the Inter-

\footnotetext{
*Corresponding author: Ki-Chang Nam, Department of Animal Science and Technology, Sunchon National University, Suncheon 540-950, Korea. Tel: +82-61-750-3231, Fax: +82-61-7503230, E-mail: kichang@scnu.kr
}

national Atomic Energy Agency (IAEA), and the US Food and Drug Administration (FDA) (Sohn et al., 2009). In Korea, 20 food items are approved to be treated by irradiation up to $10 \mathrm{kGy}$ for the purpose of inhibition of sprouting, destruction of food borne insects and parasites, delay of physiological ripening, extension of shelf life, or improvement of food qualities (MFDS, 2015). There are two common types of ionizing radiation: gamma ray and electron-beam. Electron-beam (EB) irradiation was used to inactivate foodborne pathogens during storage and to guarantee the hygienic quality of foods (Sarrias et al., 2003). EB irradiation has many advantages in industry due to the short processing time, low temperature rise, and consumer-friendliness, as it does not produce radioactive waste (Hong et al., 2008). Food irradiation causes little increase of product temperature, and can be used in a continuous process after packaging (Diehl, 2002).

Beef ageing is extensively utilized in meat industry to improve tenderness and flavor, providing more acceptable product with consumers (Troy and Kerry, 2010). Beef is generally aged at refrigerated temperature due to the microbial safety issues. The ageing time, however, can be 
shortened if the microbial safety problems can be solved at high temperatures. Ageing temperature and time were the variables that can be controlled to affect meat ageing (Lee et al., 1996).

Most research on the beef ageing has been associated with the meat quality and sensory traits (DeGeer et al., 2009). There is no previous research on inactivation of microbial spoilages of irradiated meat during the ageing process and no comparative study on the ageing time and temperature. Therefore this study was conducted to determine the effect of irradiation and ageing temperature on the microbial safety and physicochemical quality of beef during the ageing process.

\section{Materials and Methods}

\section{Sample preparation}

Eye of round (mainly Semitendinosus) beef were purchased from a local market in Daejeon, Korea. They were trimmed of all visible fat, and subsequently sliced to $1 \mathrm{~cm}$ thick pieces using a meat slicer (HFS 350G, Hankook Fugee Industries Co. Ltd., Korea). The sliced samples were individually packaged using a vacuum packaging machine (Multivac, model 1960/10, type AG800, Germany) and stored at $4^{\circ} \mathrm{C}$ overnight before irradiation.

\section{Pathogen inoculation test}

Escherichia coli O157:H7 (ATCC 43894) and Listeria monocytogenes (KCTC 3569) obtained from the Korean Collection for Type Culture (KCTC, Korea) were cultivated and the cultures were prepared with viable cell density of approximately $10^{8} \mathrm{CFU} / \mathrm{mL}$. The samples $(5 \mathrm{~g}$ ) were inoculated with $100 \mu \mathrm{L}$ of the culture solution. Each sample was then resealed and shaken for homogenization. Each prepared sample was irradiated using a linear EB $\mathrm{RF}$ accelerator (Energy $10 \mathrm{MeV}$, beam power $40 \mathrm{~kW}$ ). The employed doses were $0,0.5,1,2,3,4$, and $5 \mathrm{kGy}$.

Irradiated sample was cut into small pieces $(0.5 \mathrm{~cm} \times 0.5$ $\mathrm{cm}$ ) and homogenized for $2 \mathrm{~min}$ in a sterile Stomacher bag containing $45 \mathrm{~mL}$ of sterile saline solution using the Stomacher (BagMixer® 400, Interscience Co., France). Then samples were serially diluted in sterile saline $(0.85 \%)$ solution, and each diluent $(0.1 \mathrm{~mL})$ was spread on each bacterial media. Tryptic soy agar (Difco Laboratories) was used for E. coli O157:H7 and L. monocytogenes. Plates were incubated at $37^{\circ} \mathrm{C}$ for $48 \mathrm{~h}$, and microbial counts were expressed as CFU/g. Radiation sensitivity of the pathogens was calculated as $\mathrm{D}_{10}$, a value that represents the dose required to inactivate $90 \%$ of the microbial popula- tion.

\section{Microbial and meat quality analysis}

\section{Meat sample preparation}

Each prepared beef samples (non-sterilized) were irradiated at $2 \mathrm{kGy}$ using a linear EB RF accelerator (Energy $10 \mathrm{MeV}$, beam power $40 \mathrm{~kW}$ ). During the irradiation, nonirradiated control $(0 \mathrm{kGy})$ samples were kept at the same conditions. The irradiated and non-irradiated samples were immediately returned to a temperature of 3 different ageing temperatures $\left(2,10\right.$, or $\left.25^{\circ} \mathrm{C}\right)$. Total aerobic bacteria, E. coli, shear force, color values, and nucleotide-related flavor compounds were analyzed on non-irradiated and irradiated samples during the $8 \mathrm{~d}$ of ageing.

\section{Microbial analysis}

The sample ( $5 \mathrm{~g}$ ) was aseptically homogenized for $2 \mathrm{~min}$ in a sterile Stomacher bag containing $45 \mathrm{~mL}$ of sterile saline solution using the Stomacher BagMixer $\AA$ 400. Subsequently, the homogenized samples were serially diluted in sterile saline and plated by spreading $0.1 \mathrm{~mL}$ on a total plate count agar (Difco Laboratories) and eosin methylene blue agar (EMB, Difco) for total aerobic bacteria (TAB) counts and total coliform counts, respectively. Plates were then incubated at $37^{\circ} \mathrm{C}$ for $48 \mathrm{~h}$. The number of colonies was counted and expressed as colony forming units per gram $(\mathrm{CFU} / \mathrm{g})$.

\section{Physicochemical parameters}

Shear force (kgf) was determined using a Texture Analyzer (Model TA-XT 2i, Stable Micro system Ltd., UK) with a Warner-Bratzler-blade attachment. A meat block was cut as close as possible to $25 \times 230 \times 350 \mathrm{~mm}$ (height $\times$ width $\times$ length) and measured for shear force. The crosssections of samples (across to the fibers) were placed at middle to the blade. Crosshead speed was $200 \mathrm{~mm} / \mathrm{min}$ and full-scale load cell was $50 \mathrm{~kg}$.

The color of the beef sample surface was assayed as described by Jo et al. (2013) and evaluated using a colorimeter (Model CR-410, Konica Minolta Sensing, Inc., Japan), and L* (lightness), $\mathrm{a}^{*}$ (redness), and $\mathrm{b}^{*}$ (yellowness) were determined. The instrument was calibrated to standard black and white plates before analysis. The Hunter values were monitored by a computerized system using spectra magic software (Konica Minolta Sensing, Inc., Japan). Measurements were performed in triplicate.

Nucleotide-related flavor compounds were assayed as described by Jo et al. (2013). The meat samples ( $5 \mathrm{~g})$ were 
mixed with $25 \mathrm{~mL}$ of $0.7 \mathrm{M}$ perchloric acid and homogenized (T25b, Ika Works (Asia)., Malaysia) for $1 \mathrm{~min}$ at $1,130 \mathrm{~g}$ to extract nucleic acids. The extracted nucleic acids were centrifuged (Union 32R, Hanil Co., Ltd., Korea) for $15 \mathrm{~min}$ at 2,090 $\mathrm{g}\left(4^{\circ} \mathrm{C}\right)$ and filtered through Whatman No. 4 filter paper (Whatman Inc., Eng- land). The supernatant was then adjusted to $\mathrm{pH} 7$ with $5 \mathrm{~N} \mathrm{KOH}$ (SevenEasy, Mettler-Toledo Int. Inc., Switzerland). The $\mathrm{pH}$-adjusted supernatant was placed in a volumetric flask and adjusted to a volume of $100 \mathrm{~mL}$ with $0.7 \mathrm{M}$ perchloric acid (pH 7). After 30 min of cooling, the mixture was centrifuged (Union 32R) at 2,090 $\mathrm{g}\left(4^{\circ} \mathrm{C}\right)$ and the supernatant was filtered through a $0.2-\mu \mathrm{m}$ PVDF syringe filter (Whatman). The filtrate $(5 \mathrm{~mL})$ was analyzed using HPLC (ACME 9000, Younglin Instruments Inc., Korea). The analytical conditions for HPLC included a WatersAtlantis dC18 RP column $(4.6 \times 250 \mathrm{~mm}, 5 \mu \mathrm{m}$ particles, Waters Co., USA), with a mobile phase of $0.1 \mathrm{M}$ triethylamine in $0.15 \mathrm{M}$ acetonitrile ( $\mathrm{pH}$ 7.0). The flow rate of the mobile phase was $1.0 \mathrm{~mL} / \mathrm{min}$, and the injection volume was $10 \mu \mathrm{L}$. The column temperature was maintained at $35^{\circ} \mathrm{C}$ and detection was monitored at a wavelength of $260 \mathrm{~nm}$. The peaks of individual nucleotides were identified using retention times for the following standards: hypoxanthine, inosine, inosine-5-phosphate (IMP) (Sigma, USA); the concentrations were calculated using the area for each peak.

\section{Statistical methods}

The experiment was conducted as 3 independent trials with 3 observations for each treatment combination in each trial. Data were analyzed using SAS software (2014) (Release 8.01, SAS Institute, Inc., USA). Statistical analysis was performed by two-way (irradiation and ageing temperature) analysis of variance (ANOVA). When significant differences were detected, the differences among the mean values were determined by the Duncan's multiple comparison test at a significance level at $p<0.05$. Mean values and standard error of the means were reported.

\section{Results and Discussion}

\section{Pathogen inoculation test}

Listeria monocytogenes and E. coli were initially loaded at 8.68 and $8.54 \mathrm{Log} \mathrm{CFU} / \mathrm{g}$ in beef samples, respectively. In addition, irradiated samples had a significantly lower L. monocytogenes and E. coli population at each irradiation dose compared to non-irradiated sample. Consequently irradiation decimal reduction $\left(\mathrm{D}_{10}\right)$ values for $L$.
Table 1. $D_{10}$ values (kGy) for different pathogens inoculated in beef

\begin{tabular}{cc}
\hline \hline Pathogens & $\mathrm{D}_{10}$ values (kGy) \\
\hline Listeria monocytogenes & $0.66 \pm 0.01$ \\
Escherichia coli & $0.65 \pm 0.01$ \\
\hline
\end{tabular}

${ }^{1)}$ Means \pm standard error.

monocytogenes and E. coli inoculated in beef were 0.66 $\mathrm{kGy}$ and $0.65 \mathrm{kGy}$, respectively (Table 1 ). $\mathrm{D}_{10}$ values of bacteria in food depend on several factors including food composition, water activity, storage temperature, and presence of oxygen (Mendoca, 2002). In addition, some constituents of complex food system, such as proteins, are thought to compete with bacteria cells to interact with radiolytic free radicals, reducing the net effect of radiation damage and making the organisms more radiation-resistant (Jo et al., 2004). Kim et al. (2014) reported $\mathrm{D}_{10}$ values for $L$. monocytogenes and $E$. coli in pork jerky ranged from 0.18-0.25 kGy. Clavero et al. (1994) found $\mathrm{D}_{10}$ values for $E$. coli $\mathrm{O} 157: \mathrm{H} 7$ in ground beef at $5^{\circ} \mathrm{C}$ was 0.27 $\mathrm{kGy}$. The present results showed that EB irradiation can be effective in controlling L. monocytogenes and E. coli in beef eye of round.

\section{Microbial and meat quality during ageing}

\section{Microbial analysis}

The total aerobic bacteria (TAB) and E. coli. numbers of beef with different irradiation dose and ageing temperature are presented in Table 2. Irradiation and ageing temperature influenced $\mathrm{TAB}$ of beef. Irradiation improved the safety of beef by reducing TAB. Niemand et al. (1981) suggested the number of total aerobic bacteria was reduced by $99.9 \%$ with a dose of $2 \mathrm{kGy}$. TAB was in the range 4-5 Log CFU/g at $1 \mathrm{~d}$ and reached 6-7 Log CFU/g at $8 \mathrm{~d}$. TAB of non-irradiated samples at $8 \mathrm{~d}$ was higher by 1.2-1.4 log than those of $2 \mathrm{kGy}$-irradiated ones ( $p<$ $0.05)$. However, there were no significant differences of TAB by ageing temperature at $8 \mathrm{~d}$. It can be summarized that $2 \mathrm{kGy}$-irradiation of beef was safer than non-irradiation during the relatively high temperature ageing (10, $25^{\circ} \mathrm{C}$ ). Lee et al. (1996) mentioned irradiation resulted in a greater reduction in bacteria counts at the beginning of ageing, but the numbers was influenced by aging temperature. In addition, irradiated samples had lower E. coli population compared to non-irradiated samples (Table 2). This result confirmed that irradiation of $2 \mathrm{kGy}$ reduced the population of E. coli to an undetected level. Our investigation suggested that EB irradiation was effective red- 
Table 2. Effect of irradiation and different ageing temperature on total aerobic bacterial and $E$. coli counts of beef during the ageing

\begin{tabular}{|c|c|c|c|c|c|c|c|}
\hline \multirow{2}{*}{$\begin{array}{l}\text { Storage } \\
\text { (d) }\end{array}$} & \multirow{2}{*}{$\begin{array}{l}\text { Temperature } \\
\left({ }^{\circ} \mathrm{C}\right)\end{array}$} & \multicolumn{3}{|c|}{ Total aerobic bacteria count (Log CFU/g) } & \multicolumn{3}{|c|}{ E. coli (Log CFU/g) } \\
\hline & & Control & $\begin{array}{l}\text { Irradiated } \\
(2 \mathrm{kGy})\end{array}$ & $\mathrm{SEM}^{2)}$ & Control & $\begin{array}{l}\text { Irradiated } \\
(2 \mathrm{kGy})\end{array}$ & SEM \\
\hline \multirow{4}{*}{1} & 2 & $4.88^{\mathrm{c}}$ & $4.85^{\mathrm{b}}$ & 0.02 & $0.48^{\mathrm{b}}$ & $0.23^{\mathrm{b}}$ & 0.21 \\
\hline & 10 & $5.83^{\mathrm{ax}}$ & $4.25^{\mathrm{cy}}$ & 0.11 & $1.95^{\mathrm{ax}}$ & $0.62^{\text {by }}$ & 0.06 \\
\hline & 25 & $5.45^{\mathrm{b}}$ & $5.44^{\mathrm{a}}$ & 0.11 & $2.24^{\mathrm{ax}}$ & $1.35^{\text {ay }}$ & 0.06 \\
\hline & SEM $^{1)}$ & 0.06 & 0.12 & & 0.13 & 0.12 & \\
\hline \multirow{4}{*}{4} & 2 & $5.41^{\mathrm{bx}}$ & $5.04^{\text {by }}$ & 0.06 & $1.46^{\mathrm{b}}$ & 0.58 & 0.26 \\
\hline & 10 & $6.18^{\mathrm{abx}}$ & $4.62^{\text {cy }}$ & 0.38 & $1.21^{\mathrm{b}}$ & 0.93 & 0.35 \\
\hline & 25 & $7.14^{\mathrm{ax}}$ & $5.23^{\text {ay }}$ & 0.02 & $2.24^{\mathrm{ax}}$ & $\mathrm{ND}^{\mathrm{y}}$ & 0.03 \\
\hline & SEM & 0.32 & 0.04 & & 0.16 & 0.31 & \\
\hline \multirow{4}{*}{8} & 2 & $7.49^{x}$ & $6.10^{y}$ & 0.19 & $2.12^{x}$ & $1.52^{y}$ & 0.03 \\
\hline & 10 & $7.46^{x}$ & $6.13^{y}$ & 0.26 & $1.45^{\mathrm{x}}$ & $0.60^{y}$ & 0.32 \\
\hline & 25 & $7.46^{x}$ & $6.20^{y}$ & 0.18 & $2.36^{x}$ & $0.70^{y}$ & 0.32 \\
\hline & SEM & 0.28 & 0.10 & & 0.22 & 0.29 & \\
\hline
\end{tabular}

${ }^{1}$ Standard error of the means $(\mathrm{n}=24),{ }^{2}(\mathrm{n}=9)$.

${ }^{\mathrm{a}-\mathrm{c}}$ Figures with different letters within a same column differ significantly $(p<0.05)$.

${ }^{\mathrm{x}, \mathrm{y}}$ Figures with different letters within a same row differ significantly $(p<0.05)$.

ucing microbial levels in beef.

\section{Physicochemical meat quality}

The effect of irradiation and different ageing temperature on shear force values in beef during the aging is shown in Table 3. There was no significant difference in shear force between the control and irradiated samples $(p>0.05)$. With higher ageing temperature, shear force values decreased regardless of irradiation. The decrease in shear force may be due to the structural disruption of myofibrillar components which occurs during the ageing period (Ba et al., 2014). Similar results have found that as beef was aged longer at high temperature, shear force values decrease and the consequence of ageing was an imp- rovement in meat tenderness (Jeremiah and Gibson, 2003; Monson et al., 2004). The result shows high ageing temperature could affect shear force reduction and improve tenderness of beef. High temperature ageing can be applied to irradiated meat to shorten ageing time.

The color values of beef with different irradiation dose and ageing temperature is shown in Table 4. Hunter $\mathrm{L}^{*}$ and $b^{*}$ values were insignificantly different or inconsistent by irradiation and ageing temperature. Color $\mathrm{a}^{*}$ values were decreased by irradiation but was not different or inconsistent by ageing temperature. According to the literature, the degree of ageing was a critical factor on the redness of beef during the storage, but irradiation was the most critical factor on $a^{*}$ value of irradiated beef (Nam

Table 3. Effect of irradiation and different ageing temperature on shear force values of beef during the ageing

\begin{tabular}{|c|c|c|c|c|}
\hline \multirow{2}{*}{ Storage $(d)$} & \multirow{2}{*}{ Temperature $\left({ }^{\circ} \mathrm{C}\right)$} & \multicolumn{3}{|c|}{ Shear force values (kgf) } \\
\hline & & Control & Irradiated (2 kGy) & SEM $^{2)}$ \\
\hline \multirow{4}{*}{1} & 2 & $3.39^{\mathrm{a}}$ & $3.20^{\mathrm{a}}$ & 0.23 \\
\hline & 10 & $2.79^{\mathrm{b}}$ & $2.93^{\mathrm{a}}$ & 0.12 \\
\hline & 25 & $2.41^{\mathrm{b}}$ & $2.36^{\mathrm{b}}$ & 0.14 \\
\hline & SEM $^{1)}$ & 0.16 & 0.18 & \\
\hline \multirow{4}{*}{4} & 2 & $3.13^{\mathrm{a}}$ & $3.06^{\mathrm{a}}$ & 0.17 \\
\hline & 10 & $2.59^{\mathrm{b}}$ & $2.83^{\mathrm{a}}$ & 0.12 \\
\hline & 25 & $2.31^{\mathrm{b}}$ & $2.33^{\mathrm{b}}$ & 0.08 \\
\hline & SEM & 0.11 & 0.15 & \\
\hline \multirow{4}{*}{8} & 2 & $3.12^{\mathrm{a}}$ & $3.00^{\mathrm{a}}$ & 0.12 \\
\hline & 10 & $2.52^{\mathrm{b}}$ & $2.68^{\mathrm{a}}$ & 0.24 \\
\hline & 25 & $2.22^{b}$ & $2.16^{\mathrm{b}}$ & 0.16 \\
\hline & SEM & 0.19 & 0.17 & \\
\hline
\end{tabular}

${ }^{1)}$ Standard error of the means $(n=24),{ }^{2}(n=9)$.

${ }^{\mathrm{a}-\mathrm{c}}$ Figures with different letters within a same column differ significantly $(p<0.05)$. 
Table 4. Effect of irradiation and different ageing temperature on Hunter color values of beef during the ageing

\begin{tabular}{|c|c|c|c|c|c|c|c|c|c|c|}
\hline \multirow[b]{2}{*}{$\begin{array}{l}\text { Storage } \\
\text { (d) }\end{array}$} & \multirow[b]{2}{*}{$\begin{array}{c}\text { Temperature } \\
\left({ }^{\circ} \mathrm{C}\right)\end{array}$} & \multicolumn{3}{|c|}{$\mathrm{L}^{*}$} & \multicolumn{3}{|c|}{$\mathrm{a}^{*}$} & \multicolumn{3}{|c|}{$\mathrm{b}^{*}$} \\
\hline & & Control & $\begin{array}{c}\text { Irradiated } \\
(2 \mathrm{kGy})\end{array}$ & SEM $^{2)}$ & Control & $\begin{array}{c}\text { Irradiated } \\
(2 \mathrm{kGy})\end{array}$ & SEM & Control & $\begin{array}{c}\text { Irradiated } \\
(2 \mathrm{kGy})\end{array}$ & SEM \\
\hline \multirow{4}{*}{1} & 2 & $37.05^{\mathrm{a}}$ & 35.61 & 0.68 & 20.55 & $19.07^{\mathrm{a}}$ & 0.59 & 7.00 & $6.96^{\mathrm{a}}$ & 0.50 \\
\hline & 10 & $35.41^{\mathrm{b}}$ & 34.74 & 0.39 & $19.73^{x}$ & $17.13^{\text {by }}$ & 0.17 & $6.61^{x}$ & $4.55^{\text {by }}$ & 0.14 \\
\hline & 25 & $37.87^{\mathrm{a}}$ & 37.25 & 0.71 & $19.84^{x}$ & $18.09^{\text {aby }}$ & 0.35 & $7.39^{x}$ & $6.35^{\text {ay }}$ & 0.28 \\
\hline & SEM $^{1)}$ & 0.45 & 0.74 & & 0.27 & 0.51 & & 0.25 & 0.41 & \\
\hline \multirow{4}{*}{4} & 2 & $37.15^{x}$ & $34.57^{\mathrm{cy}}$ & 0.59 & 18.97 & 17.83 & 0.79 & 5.13 & 5.16 & 0.67 \\
\hline & 10 & 37.71 & $37.26^{\mathrm{b}}$ & 0.35 & $20.53^{x}$ & $18.04^{y}$ & 0.41 & 6.34 & 5.48 & 0.39 \\
\hline & 25 & 37.85 & $38.96^{\mathrm{a}}$ & 0.63 & 18.91 & 17.44 & 0.50 & 4.94 & 6.26 & 0.60 \\
\hline & SEM & 0.63 & 0.42 & & 0.59 & 0.59 & & 0.61 & 0.52 & \\
\hline \multirow{4}{*}{8} & 2 & $39.33^{\text {ax }}$ & $36.07^{\text {by }}$ & 0.62 & $22.62^{\text {ax }}$ & $18.52^{\text {aby }}$ & 0.53 & 7.79 & $6.56^{\mathrm{b}}$ & 0.79 \\
\hline & 10 & $35.40^{\text {by }}$ & $37.49^{\mathrm{abx}}$ & 0.52 & $20.60^{\text {bx }}$ & $16.70^{\text {by }}$ & 0.67 & $7.96^{x}$ & $4.94^{\text {cy }}$ & 0.54 \\
\hline & 25 & $39.07^{\mathrm{a}}$ & $38.13^{\mathrm{a}}$ & 0.57 & $21.69^{\mathrm{abx}}$ & $20.30^{\text {ay }}$ & 0.42 & 8.92 & $8.74^{\mathrm{a}}$ & 0.31 \\
\hline & SEM & 0.57 & 0.57 & & 0.43 & 0.65 & & 0.63 & 0.53 & \\
\hline
\end{tabular}

${ }^{1)}$ Standard error of the means $(\mathrm{n}=24),{ }^{2)}(\mathrm{n}=9)$.

${ }^{\mathrm{a}-\mathrm{c}}$ Figures with different letters within a same column differ significantly $(p<0.05)$.

${ }^{\mathrm{x}, \mathrm{y}}$ Figures with different letters within a same row differ significantly $(p<0.05)$.

Table 5. Effect of irradiation and different ageing temperature on nucleotide-related compounds of beef treated by electron beam irradiation

\begin{tabular}{|c|c|c|c|c|c|c|c|c|c|c|}
\hline \multirow{2}{*}{$\begin{array}{l}\text { Storage } \\
\text { (d) }\end{array}$} & \multirow{2}{*}{$\begin{array}{c}\text { Temperature } \\
\left({ }^{\circ} \mathrm{C}\right)\end{array}$} & \multicolumn{3}{|c|}{ IMP } & \multicolumn{3}{|c|}{ Inosine } & \multicolumn{3}{|c|}{ Hypoxanthine } \\
\hline & & Control & $\begin{array}{c}\text { Irradiated } \\
(2 \mathrm{kGy})\end{array}$ & SEM $^{2)}$ & Control & $\begin{array}{c}\text { Irradiated } \\
(2 \mathrm{kGy})\end{array}$ & SEM & Control & $\begin{array}{c}\text { Irradiated } \\
(2 \mathrm{kGy})\end{array}$ & SEM \\
\hline \multirow{4}{*}{1} & 2 & $75.72^{\mathrm{ax}}$ & $37.11^{\text {by }}$ & 9.63 & $24.77^{\mathrm{a}}$ & 19.22 & 3.79 & $18.41^{b}$ & $20.16^{\mathrm{ab}}$ & 1.07 \\
\hline & 10 & $88.94^{\mathrm{a}}$ & $97.97^{\mathrm{a}}$ & 3.80 & $25.49^{\mathrm{ax}}$ & $21.71^{y}$ & 0.80 & $16.74^{\text {by }}$ & $19.12^{\mathrm{bx}}$ & 0.57 \\
\hline & 25 & $37.63^{b}$ & $30.84^{\mathrm{b}}$ & 9.98 & $17.51^{\mathrm{b}}$ & 20.89 & 2.45 & $22.72^{\mathrm{a}}$ & $23.49^{\mathrm{a}}$ & 0.87 \\
\hline & SEM $^{1)}$ & 4.65 & 10.78 & & 1.27 & 3.52 & & 0.74 & 0.96 & \\
\hline \multirow{4}{*}{4} & 2 & $68.74^{\mathrm{a}}$ & $76.80^{\mathrm{a}}$ & 6.38 & $26.42^{\mathrm{ax}}$ & $19.25^{\mathrm{ay}}$ & 0.84 & $18.38^{\text {by }}$ & $19.67^{\mathrm{bx}}$ & 0.25 \\
\hline & 10 & $56.46^{\mathrm{a}}$ & $75.12^{\mathrm{a}}$ & 6.14 & $15.32^{\text {by }}$ & $22.26^{\mathrm{ax}}$ & 1.37 & $22.09^{\mathrm{ab}}$ & $21.97^{\mathrm{b}}$ & 0.52 \\
\hline & 25 & $3.21^{\mathrm{b}}$ & $5.05^{\mathrm{b}}$ & 0.76 & $1.66^{\mathrm{c}}$ & $5.88^{\mathrm{b}}$ & 1.65 & $28.49^{\mathrm{a}}$ & $28.18^{\mathrm{a}}$ & 2.58 \\
\hline & SEM & 6.96 & 2.04 & & 1.06 & 1.55 & & 1.93 & 0.96 & \\
\hline \multirow{4}{*}{8} & 2 & $64.88^{\mathrm{ax}}$ & $33.10^{\text {ay }}$ & 3.99 & $23.52^{\mathrm{ax}}$ & $17.92^{\mathrm{ay}}$ & 0.95 & $18.32^{\text {by }}$ & $21.66^{\mathrm{cx}}$ & 0.42 \\
\hline & 10 & $11.71^{\mathrm{bx}}$ & $3.61^{\text {by }}$ & 0.56 & $2.66^{\mathrm{b}}$ & $5.86^{\mathrm{b}}$ & 2.93 & $24.81^{\mathrm{a}}$ & $27.69^{\mathrm{b}}$ & 0.95 \\
\hline & 25 & $3.44^{\text {cy }}$ & $8.00^{\mathrm{bx}}$ & 0.49 & $2.47^{\mathrm{b}}$ & $2.15^{\mathrm{b}}$ & 0.54 & $26.55^{\text {ay }}$ & $34.59^{\mathrm{ax}}$ & 1.45 \\
\hline & SEM & 0.52 & 3.28 & & 0.72 & 2.45 & & 1.26 & 0.72 & \\
\hline
\end{tabular}

${ }^{1)}$ Standard error of the means $(n=24),{ }^{2}(n=9)$.

${ }^{\mathrm{a}-\mathrm{c}}$ Figures with different letters within a same column differ significantly $(p<0.05)$.

${ }^{x, y}$ Figures with different letters within a same row differ significantly $(p<0.05)$.

and Ahn, 2003). In the present study, a* values decreased by irradiation throughout the storage and the irradiated beef had lower a* values than non-irradiated sample. This result agrees with other authors who reported that irradiated beef reduced $\mathrm{a}^{*}$ values during storage (Ahn and Nam, 2004; Nam and Ahn, 2003). Luschinger et al. (1997) reported that irradiation at 2.0 and $3.5 \mathrm{kGy}$ initially reduced the redness of raw beef patties in aerobic or vacuum packaging, but the color difference disappeared with display time. Nanke (1998) suggested that color changes of irradiated raw meat were dependent on species, irradiation dose, and packaging type.

\section{Nucleotide-related compounds}

Nucleotide-related flavor compounds can be formed from the decomposition of adenosine-5-triphosphate (ATP) (Flores et al., 1999). ATP is major compound in muscle before slaughter, whereas muscle after slaughter contains large amounts of inosine monophosphate (IMP) and small amounts of ATP, adenosine-5-monophosphate (AMP), and adenosine-5-diphosphate ADP (Lee and Lee, 2001). During beef ageing, ATP converts into AMP by dephosphorylating and then becomes to IMP which provides good flavor to meat. IMP eventually changes to inosine with a sour taste and then to hypoxanthine with a bitter taste (Tikk et al., 2006). 
The nucleotide-related compounds of beef were influenced by ageing time and temperature (Table 5). As accordant to the previous studies, the amounts of IMP decreased and hypoxanthine increased with increasing ageing time. With higher ageing temperature, the IMP decreased and hypoxanthine increased indicating the IMP is transformed into inosine and hypoxanthine. Thus the conversion of IMP to hypoxanthine was accelerated by high temperature of ageing. At $4 \mathrm{~d}$, beef samples at $25^{\circ} \mathrm{C}$ had significantly lower IMP and greater hypoxanthine compared with the samples at $2^{\circ} \mathrm{C}$ or $10^{\circ} \mathrm{C}$ in the samples, regardless of irradiation. At $8 \mathrm{~d}$, beef samples with high ageing temperature $\left(10^{\circ} \mathrm{C}, 25^{\circ} \mathrm{C}\right)$ had lower IMP and greater hypoxanthine than $2^{\circ} \mathrm{C}$. Although high temperature ageing had excellent tenderness in irradiated beef, the specific ageing temperature should be selected considering other meat quality parameters such as flavor compounds.

\section{Conclusion}

EB irradiation was an effective to reduce the risk of foodborne pathogens of beef, and can be used for beef ageing at high temperature to shorten ageing time. Ageing beef at high temperatures $\left(10^{\circ} \mathrm{C}, 25^{\circ} \mathrm{C}\right)$ accelerated the tenderization of irradiated beef. Nevertheless, irradiated beef ageing at $25^{\circ} \mathrm{C}$ was problematic in the profile of nucleotide-related flavor compounds, as hypoxanthine was fast transformed from IMP. An optimal ageing condition of irradiated beef can be suggested as $4 \mathrm{~d}$ at $10^{\circ} \mathrm{C}$, considering meat quality and safety.

\section{Acknowledgements}

This work was supported from Radiation Technology R\&D program (2013M2A2A6043308) through the National Research Foundation of Korea funded by the Ministry of Science, ICT \& Future Planning.

\section{References}

1. Ahn, D. U. and Nam, K. C. (2004) Effects of ascorbic acid and antioxidants on color, lipid oxidation and volatiles of irradiated ground beef. Radiat. Phys. Chem. 71, 149-154.

2. Artes, F., Gomez, P., and Artes-Hernandez, F. (2007) Physical, physiological and microbial deterioration of minimally fresh processed fruits and vegetables. Food Sci. Technol. Int. 13, 177-188.

3. Ba, H. V., Park, K., Dahmaa, D., and Hwang, I. (2014) Effect of muscle type and vacuum chiller ageing period on the chemical compositions, meat quality, sensory attributes and vol- atile compounds of Korean native cattle beef. Animal Sci. J. 85, 164-173.

4. Clavero, M. R., Monk, J. D., Beuchat, L. R., Doyle, M. P., and Brackett, R. E. (1994) Inactivation of Escherichia coli O157:H7, salmonellae, and Campylobacter jejuni in raw ground beef by gamma irradiation. Appl. Environ. Microbiol. 60, 2069.

5. DeGeer, S. L., Hunt, M. C., Bratcher, C. L., Crozier-Dodson, B. A., Johnson, D. E., Stika, and J. F. (2009) Effects of dry aging of bone-in and boneless strip loins using two aging processes for two aging times. Meat Sci. 83, 768-774.

6. Diehl, J. F. (2002) Food irradiation-past, present and future. Radiat. Phys. Chem. 63, 211-215.

7. Flores, M., Armero, E., Aristoy, M. C., and Toldra, F. (1999) Sensory characteristics of cooked pork loin as affected by nucleotide content post-mortem meat quality. Meat Sci. 51, 53-59.

8. Hong, Y. H., Park, J. Y., Park, J. H., Chung, M. S., Kwon, K. S., Chung, K., Won, M., and Song, K. B. (2008) Inactivation of Enterobacter sakazakii, Bacillus cereus, and Salmonella typhimurium in powdered weaning food by electron-beam irradiation. Radiat. Phys. Chem.77, 1097-1100.

9. Jeremiah, L. E. and Gibson, L. L. (2003) The effects of postmortem product handling and aging time on beef palatability. Food Res. Int. 36, 929-941.

10. Jo, C., Jayasena, D. D., Lim, D. G., Lee, K. H., Kim, J. J., Cha, J. S., and Nam, K. C. (2013) Effect of intramuscular fat content on the meat quality and antioxidative dipeptides of Hanwoo beef. Korean J. Food Nutr. 26, 117-124.

11. Jo, C., Lee, N. Y., Kang, H. J., Shin, D. H., and Byun, M. W. (2004) Inactivation of foodborne pathogens in marinated beef rib by ionizing radiation. Food Microbiol. 21, 543-548.

12. Kim, H. J., Jung, S., Yong, H. I., Bae, Y. S., Kang, S. N., Kim, I. S., and Jo, C. (2014) Improvement of microbiological safety and sensorial quality of pork jerky by electron beam irradiation and by addition of onion peel extract and barbecue flavor. Radiat. Phys. Chem. 98, 22-28.

13. Lee, K. H. and Lee, Y. S. (2001) Changes of nucleotides and their related compounds in cultured and wild red sea bream and flounder muscle. Korean J. Food Soc. Cookery Sci. 17, 517-522.

14. Lee, M., Sebranek, J., and Parrish Jr., F. C. (1996) Accelerated postmortem aging of beef utilizing electron-beam irradiation and modified atmosphere packaging. J. Food Sci. 61, 133-136.

15. Luschinger, S. E., Kropf, D. H., Garcia-Zepeda, C. M., Hunt, M. C., Stroada, S. L., Marsden, J. L., and Kastner, C. L. (1997) Color and oxidative properties of irradiated ground beef patties. J. Muscle Foods. 8, 445-464.

16. Mendoca, A. F. (2002) Inactivation by irradiation, in: Juneja, V. K. and Sofos, J. N. (Eds.), Control of foodborne pathogens. Marcel Dekker, New York, pp. 75-104.

17. MFDS (2015) Standard for irradiation. Korean Food Standards Codex. Ministry of food and drugs safety.

18. Monson F., Sanudo C., and Sierra I. (2004) Influence of cattle breed and ageing time on textural meat quality. Meat Sci. 
68, 595-602.

19. Nam, K. C. and Ahn, D. U. (2003) Effects of ascorbic acid and antioxidants on the color of irradiated ground beef. $J$. Food Sci. 68, 1686-1690.

20. Nanke, K. E. (1998) Effects of ionizing radiation on pork, beef, and turkey quality. Ph.D. thesis. Iowa State University.

21. Niemand, J. G., Vanderlinde, H. J., and Holzapfel, W. H. (1981) Radurization of prime beef cuts. J. Food Prot. 44, 677-681.

22. SAS (2014) SAS/STAT Software for PC. Release 6.11, SAS Institute, Cary, NC, USA.

23. Sarrias, J. A., Valero, M., and Salmeron, M. C. (2003) Elimination of Bacillus cereus contamination in raw rice by electron beam irradiation. Food Microbiol. 20, 327-332.

24. Sohn, S. H., Jang, A., Kim, J. K., Song, H. P., Kim, J. H., Lee, M., and Jo, C. (2009) Reduction of irradiation off-odor and lipid oxidation in ground beef by a-tocopherol addition and the use of a charcoal pack. Radiat. Phys. Chem. 78, 141-146.

25. Tikk, M., Tikk, K., Torgen, M. A., Meinert, L., Aaslyng, M. D., Karlsson, A. H., and Anderson, H. J. (2006) Development of inosine monophosphate and its degradation products during aging of pork of different qualities in relation to basic taste and retronasal flavor perception of the meat. J. Agric. Food Chem. 54, 7769-7777.

26. Troy, D. J. and Kerry, J. P. (2010) Consumer perception and the role of science in the meat industry. Meat Sci. 86, 214226.

27. World Health Organization (WHO) (1999) High dose irradiation: Wholesomeness of food irradiated with doses above 10 kGy. WHO Technical Report Series 890. Geneva, pp. 9-37. 